\title{
A prenatal tertiary trisomy resulting from balanced maternal 8; 9 translocation
}

\author{
Annenin dengeli 8; 9 translokasyonu sonucu oluşan prenatal tersiyer trizomi
}

\author{
Gülsüm Kayhan ${ }^{1}$, Mehmet Ali Ergün ${ }^{1}$, Aydan Asyalı Biri², Meral Yirmibeş Karaoğuz ${ }^{1}$ \\ 'Department of Medical Genetics, Faculty of Medicine, Gazi University, Ankara, Turkey \\ ${ }^{2}$ Department of Obstetrics and Gynecology, Faculty of Medicine, Gazi University, Ankara, Turkey
}

\section{Abstract}

An additional derivative chromosome 8 was found in the cytogenetic analyses of the chorionic villus biopsy specimen of a balanced reciprocal translocation carrier mother. This was a 3:1 segregation of the unbalanced product of the balanced maternal 8:9 translocation. The chromosomes of the carrier of the balanced reciprocal translocation pair with their matching homologous segments at meiosis I, a quadrivalent figure is formed and chromosomes segregate from this configuration. Increased nuchal tranaslucency was also determined on fetal sonography at the $13^{\text {rd }}$ week of gestation. The final karyotype was $47, \mathrm{X} Y,+\operatorname{der}(8) \mathrm{t}(8 ; 9)(\mathrm{q} 11.2 ; \mathrm{p} 22) \mathrm{mat}$, and the parents were informed about this tertiary trisomy. After genetic counseling, the parents decided to terminate the pregnancy. The presented case is a reminder of the probability of the unbalanced products of the $3: 1$ segregation, rather than the common 2:2 segregation.

(J Turkish-German Gynecol Assoc 2011; 12: 183-5)

Key words: Derivative chromosome 8, nuchal translucency, reciprocal translocation, tertiary trisomy, 3:1 segregation

Received: 17 August, 2010

Accepted: 09 September, 2010
Özet

Dengeli resiprokal translokasyon taşıyıcısı annenin, koryon villüs biyopsi materyalinden yapılan sitogenetik analizinde, ek olarak derivatif 8. kromozom belirlenmiştir. Bu dengesiz durum, 8. ve 9. kromozomlar arasında dengeli resiprokal translokasyon içeren annenin, 3:1 gamet ayrışımından kaynaklanmaktadır. Resiprokal dengeli translokasyon taşıyıcılarının kromozomlanı, mayoz 1'de homologlanı ile eşleşebilmek için quadrivalen yapıyı oluşturmakta ve buradan kromozomların segregasyonu sözkonusu olmaktadır. Gebeliğin 13. haftasında yapılan fetal ultrasonografide ayrıca nukkal kalınlık artışı saptanmıştır. Fetüsün karyotipi $47, \mathrm{XY},+\operatorname{der}(8) \mathrm{t}(8 ; 9)(\mathrm{q} 11.2 ; \mathrm{p} 22)$ mat olarak rapor edilmiş ve tersiyer trizomi hakkında aileye bilgi verilmiştir. Aile genetik danışmanlık sonrası gebeliğini sonlandırmaya karar vermiştir. Burada sunulan olgu, resiprokal translokasyon taşıyıcılarının dengesiz gamet oluşumunda 2:2 segregasyonun yanısıra, daha az oranda da olsa 3:1 segregasyon olasılığının da olduğunu hatırlatması açısından önemlidir. (J Turkish-German Gynecol Assoc 2011; 12: 183-5)

Anahtar kelimeler: Derivatif 8. kromozom, nukkal kalınlık, resiprokal translokasyon, tersiyer trizomi, 3:1 segregasyon

Geliş Tarihi: 17 Ağustos 2010

Kabul Tarihi: 09 Eylül 2010

\section{Introduction}

Reciprocal translocations are structural chromosomal abnormalities commonly seen in humans, with a frequency of 1:500. The phenotype of the balanced translocation carriers is usually normal; however, they have significant risks of unbalanced progeny or spontaneous abortion (1-3). At meiosis I, the translocated chromosomes pair with their matching homologous at a quadrivalent formation and imbalanced gametes result from the disjunction of these chromosomes for the segregation models i.e. adjacent 1, adjacent 2, 3:1, 4:0 $(1,2)$.

Offspring of carriers often have 46 chromosomes, including one of the derivative chromosome, so are partially trisomic and partially monosomic for the translocated chromosomes. Nevertheless, a karyotype with 47 or 45 chromosomes due to $3: 1$ segregation is often complicated by the presence of two partial trisomies or regular and partial monosomies; namely tertiary trisomy/monosomy and interchange trisomy/monosomy. Here, we presented a prenatal tertiary trisomic case with the partial trisomy $8 \mathrm{p}$ (and also including a tiny part of $8 \mathrm{q} ; 8 \mathrm{q} 11.2$ ) and the partial trisomy $9 \mathrm{p}$ due to $3: 1$ segregation derived from balanced maternal 8;9 translocation.

\section{Case Report}

A 33 year old balanced reciprocal translocation carrier, was referred to us at the $14^{\text {th }}$ week of her third gestation for prenatal cytogenetic analyses. The parent was informed and then signed the informed consent for the invasive prenatal sampling and cultivation of the chorionic villus biopsy specimen. Her first pregnancy had ended with spontaneous abortion at the $7^{\text {th }}$ week and they had a 2-year-old healthy boy from the second pregnancy. Chromosome analyses of the parent had been performed in our laboratory after the first pregnancy and the mother was diagnosed as a balanced reciprocal translocation carrier $[\mathrm{t}(8 ; 9)(\mathrm{q} 11.2 ; \mathrm{p} 22)]$ (Figure 1). In this progeny at the $13^{\text {rd }}$ week of gestation, a thickened nuchal fold $(10 \mathrm{~mm})$ was also found on fetal sonography. G-banding 


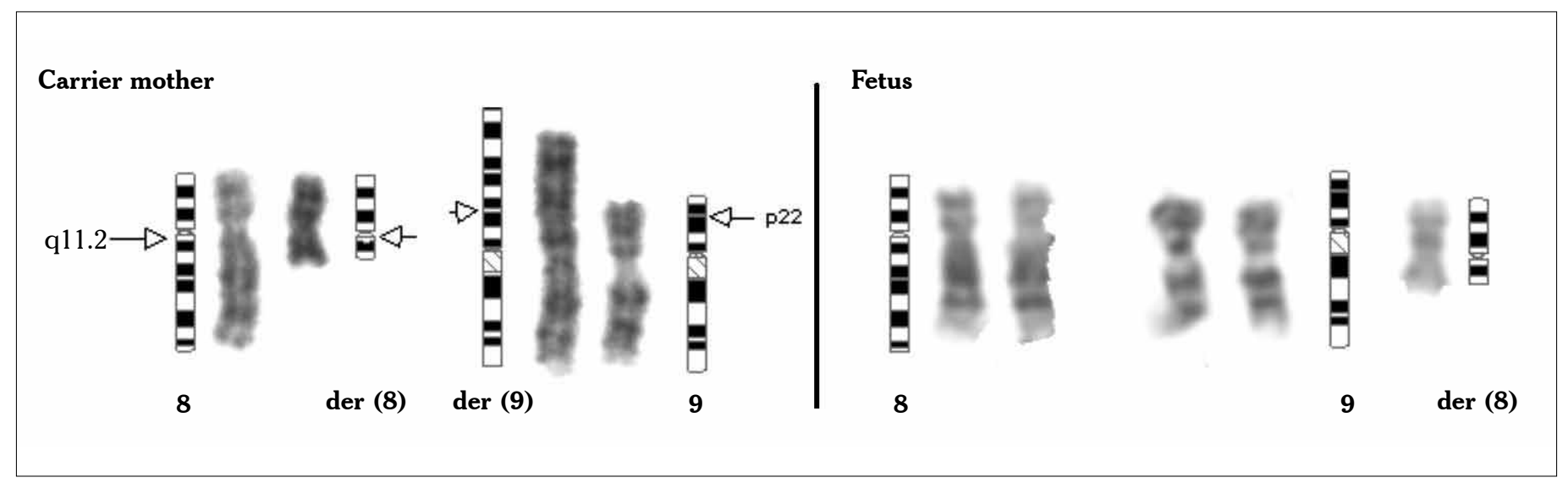

Figure 1. GTG banded partial karyotype and ideogram of carrier mother (left) and the imbalance fetus (right). The arrows indicate the breakpoints

for short-term and long-term tissue cultures and Fluorescence in situ hybridization (FISH) technique were performed on the chorionic villus biopsy specimen. FISH was informative for the common aneuploidies but not for the reciprocal translocation because of the lack of the specific probes for the chromosomal rearrangement. We could not obtain a qualified chromosome from short-term tissue culture and the long-term tissue culture result was 47,XY,+der(8)t(8;9)(q11.2;p22)mat (Figure 1). Breakpoints of the derivative chromosome involved the same bands; $8 \mathrm{q} 11.2$ and 9p22, as the mother. This was a tertiary trisomy for the whole short arm and a small part of the long arm of the chromosome 8 (8pter $\rightarrow 8 \mathrm{q} 11.2)$ and the partial short arm of the chromosome 9 (9pter $\rightarrow 9 \mathrm{p} 22)$ resulting from the $3: 1 \mathrm{seg}-$ regation of the balanced maternal 8;9 translocation.

The pregnancy was terminated in the $15^{\text {th }}$ week of gestation at another center. We could not evaluate the physical properties, but only learnt from the information obtained from the mother that the fetus had frontal bossing and hypertrichosis.

We could not evaluate the physical properties, only the information obtained from the mother that the fetus had frontal bossing and hypertrichosis.

\section{Discussion}

Balanced reciprocal translocations are usually harmless rearrangements for the carriers, but the derivative chromosomes and their matching homologous form a quadrivalent figure at meiosis I and 2:2, 3:1, and 4:0 segregation models yield mostly unbalanced gametes. The rates of segregant distributions are not a significant distinction in each sex, except the 3:1 category and a predisposition for 3:1 segregation in oogenesis can be confirmed (4-7). The factor for the possibility of segregant models produced by Daniel A (1979), is the percentage of the total haploid autosomal lentgh (HAL) (8). As a viability conceptus, if one of the translocated or derivative chromosomes is small, similar to our case, 3:1 segregation is more likely than the other segregation models $(9,10)$.

The living patients with tertiary trisomy are mostly reported for chromosome $9 p(11,12)$. The distal half of the short arm of chromosome 9p (9pter-9p21), approximately the same seg- ment as our case (9pter-9p22) (Figure 1), is responsible for the major clinical features of the syndrome; growth and mental retardation, ear anomalies, hypertelorism etc. (12). The reported cases with trisomy $8 p$, are generally results of the inversion duplication and of the reciprocal translocations, and their clinical features are hypotonia, neonatal feeding problems, mental retardation, brain and orthopedic abnormalities and specific facial features $(13,14)$. As far as we know, there is no report which met all the criteria of the translocated segments of our case. A case of trisomy 8p12-pter, quite similar to our case (trisomy 8q11.2-pter) resulting from $8 ; 15$ balanced maternal translocation, had similar findings of the other trisomy 8, however, since our case was detected prenatally, we could not evaluate the clinical findings except for the increased nuchal translucency on fetal sonography (14). Nuchal translucency thickness shows an increased risk for trisomies 13, 18 and 21, this also may be true for other regular trisomies and/or tertiary trisomies as well (15). This information can be helpful in genetic counseling and for decision making. The recurrence risk of unbalanced infants is the second important parameter for the reciprocal translocation carriers and their proceeding gestations. The risk from 3:1 disjunction is similar to that for other imbalanced offspring; only the abortion rate for $3: 1$ disjunction is higher than others (2).

In conclusion, in the couples with chromosomal rearrangement and/or with abnormal fetal sonography findings, cytogenetic analyses and chromosome specific FISH paintings should be performed in the prenatal period. While providing genetic counseling, not only the unbalanced gametes due to $2: 2 \mathrm{seg}$ regation but also the risk of unbalanced progenies from 3:1 disjunction should be considered and pre-implantation genetic diagnosis could be suggested.

\section{Conflict of interest}

No conflict of interest was declared by the authors.

\section{References}

1. Suguiura-Ogasawara M, Ozaki Y, Sato T, Suzumori N, Suzumori K. Poor prognosis of recurrent aborters with either maternal or paternal reciprocal translocations. Fertil Steril 2004; 81: 367-73. 
2. Lindenbaum RH, Bobrow M. Reciprocal translocations in man. 3:1 meiotic disjunction resulting in 47 or 45 chromosome offspring. Journal of Medical Genetics 1975; 12: 29-43. [CrossRef]

3. Karaer K, Yirmibeş Karaoğuz M, Pala E, Erdem A. Relationship between prenatally determined familial reciprocal translocations (1q23;19q13.3) breakpoints and malignancies and genetic counseling. Prenatal tanıda belirlenen ailesel translokasyonun (1q23;19q13.3) kırık bölgelerinin malignensilerle ilişkisi ve genetik danışma. J Turkish- German Gynecol Assoc 2006; 7: 356-8.

4. Estop AM, Van Kirk V, Cieply K. Segregation analysis of fourtranslocations, $\mathrm{t}(2 ; 18), \mathrm{t}(3 ; 15), \mathrm{t}(5 ; 7)$, and $\mathrm{t}(10 ; 12)$, by spermchromosome studies and a review of the literature. Cytogenet Cell Genet 1995; 70: 80-8. [CrossRef]

5. Guttenbach M, Engel W, Schmid M. Analysis of structural and numerical chromosome abnormalities in sperm of normal men and carriers of constitutional chromosome aberrations. A review. Hum Genet 1997; 100: 1-21. [CrossRef]

6. Munne S, Scott R, sable D, Cohen J. First pregnancies after preconception daignosis of translocations of maternal origin. Fertil Steril 1998; 69: 675-81

7. Mackie Ogilvie C, Scriven PN. Meiotic outcomes in reciprocal translocation carriers ascertained in 3-day human embryos. Eur J Hum Genet 2002; 10: 801-6. [CrossRef]

8. Daniel A. Structural differences in reciprocal translocations: Potential for a model of risk in rcp. Hum Genet 1979; 51: 171-82. [CrossRef]
9. Jalbert P, Sele B, Jalbert H. Reciprocal translocations: a way to predict the mode of imbalanced segregation by pachytene-diagram drawing. Hum Genet 1980; 55: 209-22. [CrossRef]

10. Jalbert, P., Jalbert, H., Sele, B. Types of imbalances in human reciprocal translocations: risks at birth. In " The Cytogenetics of Mammalian Autosomal Rearrangements”. A. Daniel ed. Alan R Liss, New York, 1988 pp. 267-91.

11. Littooij AS, Hochstenbach R, Sinke RJ, van Tintelen P, Giltay JC. Two cases with partial trisomy 9p: molecular cytogenetic characterization and clinical follow-up. Am J Med Genet 2002; 109: 125-32. [CrossRef]

12. Lewandowski RC Jr, Yunis JJ, Lehrke R, O'Leary J, Swaiman KF, Sanchez O. Trisomy for the distal half of the short arm of chromosome 9. A variant of the trisomy 9p syndrome. Am J Dis Child 1976; 130: 663-7.

13. Engelen JJM, Die-Smulders CEM, Sijstermans JMJ. Familial partial trisomy 8p without dysmorphic features and only mild mental retardation. J Med Genet 1995; 32: 792-5. [CrossRef]

14. Jones LA, Dengler DR, Taysi K, Shackelford Gd, Hartman AF. Partial trisomy of the short arm of chromosome 8 resulting from balanced maternal translocation. J Med Genet 1980; 17: 232-5. [CrossRef]

15. Pandya PP, Brizot ML, Kuhn P, Snijders RJ, Nicolaides KH. Firsttrimester fetal nuchal translucency thickness and risk for trisomies. Obstet Gynecol 1994; 84: 420-3. [CrossRef] 